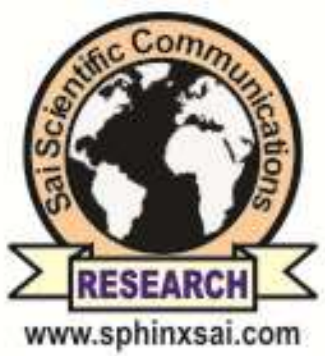

International Journal of PharmTech Research
CODEN (USA): IJPRIF, ISSN: 0974-4304, ISSN(Online): 2455-9563

\title{
Pharmacognostical, Phytochemical investigations on whole plant of Cleome chelidonii Linn
}

\author{
V.Kavitha*, T.Shri Vijaya Kirubha, R. Senthamarai, P.Balasubramanian \\ Department of Pharmacognosy, Periyar College of Pharmaceutical Sciences, \\ Tiruchirappalli -620 021, Tamil Nadu, India
}

\begin{abstract}
Cleome chelidonii Linn. (Family: Capparaceae) is a rare plant grown as perennials throughout dry seasons and widely distributed as a weed in wet places. However, the plant having wide therapeutic properties has not been scientifically validated. In present investigation, the detailed Pharmacognostical study of Cleome chelidonii is carried out to lay down the standards which could be useful in future experimental studies. The study includes macroscopy, microscopy, preliminary phytochemical screening, separation and isolation of plant constituents by chromatographic methods, characterization of isolated plant constituents and fluorescence analysis, elemental analysis and spectral studies. These studies provided referential information for correct identification and standardization of this plant material and to differentiate the plant Cleome chelidonii from other species of Cleome.
\end{abstract}

Keywords : Cleome chelidonii - Morphology, Histology, Phytochemical studies, Column chromatography, HPTLC.

\section{Introduction}

Herbal medicines are now in a great demand in the developing world for primary health care not because they are inexpensive but also for better cultural acceptability, better compatibility with the human body and minimal side effects. Standardization and validation is very important for the herbal drugs. Herbal medicine is the oldest form of healthcare known to mankind. Herbs had been used by all cultures throughout history. It was an integral part of the development of modern civilization. Primitive man observed and appreciated the great diversity of plants available to him. Much of the medicinal use of plants seems to have been developed through observations of wild animals and by trial and error. ${ }^{[1]}$

Herbal drugs constitute a major share of all the officially recognized systems of health in India. More than $70 \%$ of India's population still use these systems of medicine. Currently there is no separate category of herbal drugs or dietary supplements, as per the Indian Drugs Act. However, there is a vast experimental studies evidence base for many of the natural drugs. Evidence based herbals are widely used in the diverse systems and manufactured as per the Pharmacopoeial guidelines by a well organized industry. ${ }^{[2]}$

V.Kavitha et al / International Journal of PharmTech Research, 2020,13(2): 51-59.

DOI= http://dx.doi.org/10.20902/IJPTR.2019.130208 
The plant Cleome chelidonii Linn. (Family: Capparaceae) is grown as perennials throughout dry seasons and widely distributed as a weed in wet places ${ }^{[3]}$.It is found in India, Myanmar, Malaysia, Indo China and Java. In Tamil it is called Neela Naikadugu ${ }^{[4]}$. However, the plant having wide therapeutic properties has not been scientifically validated.The leaves of Cleome chelidonii is generally known to be used for the treatment of colic, dysentery, headache, otitis, and rheumatism. The whole plant has also been found to possess multiple therapeutic properties such as its use a vermifuge, in the treatment of skin diseases including leucoderma, and with anti-inflammatory, anti microbial, anti nociceptive and anti pyretic properties ${ }^{[5-8]}$. The objective of the presentwork has been aimed to investigate the Pharmacognostical and Phytochemical properties of the plant Cleome chelidonii.

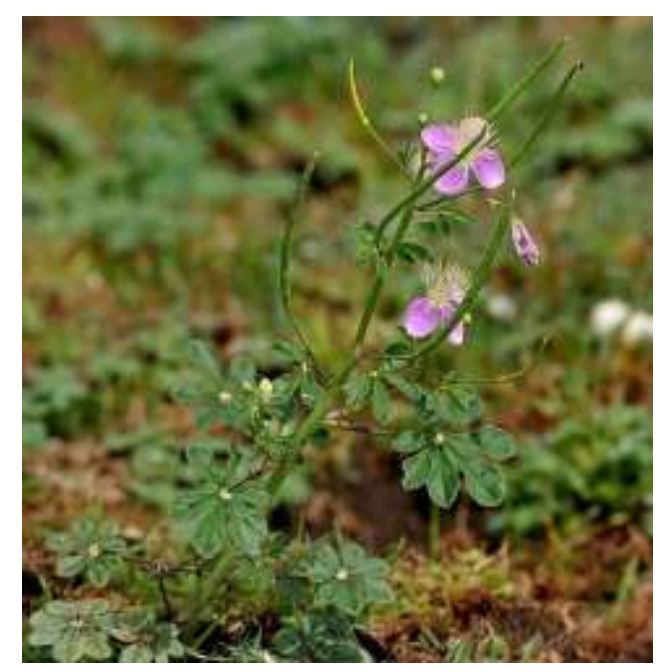

Fig. 1 :Whole Plant of Cleome chelidonii

\section{Materials and Methods}

\section{Collection and Authentication of the Plant material}

The fresh plant material was collected from Tiruchirappalli, Tamil Nadu in the month of June 2019.The plant material was taxonomically authenticated for its botanical identity by Botanist, and voucher specimen deposited in herbarium of the institute. Transverse section of leaf along the midrib, stem and roots were done. The coarsely powered plant material was subjected to extraction by solvents with increasing polarityand the dried extracts were subjected to phytochemical studies using standard test procedures.

\section{Observations}

\section{Morphology:}

$\begin{array}{lcc}\text { Height } & - & 0.3-0.9 \mathrm{~m} . \\ \text { Leaves } & - & 1-\text { or } 3-\text { foliate at the top and } 5 \text { - or 7-foliate at the base } \\ \text { Leaflets } & - & \text { obovate, } 2-3 \mathrm{~cm} \text { long, } 0.5-1.5 \mathrm{~cm} \text { wide. } \\ \text { Stem branches } & - & \text { striate, glabrous. } \\ \text { Flowers } & - & 4, \text { rose coloured petals, and big mass of over } 100 \\ & & \text { stamens in the center. Capsule is hairless. } \\ \text { Pods } & - & 5-6 \mathrm{~cm} \text { in length. } \\ \text { Seeds } & - & \text { asymmetrical, spherical to oval, comma shaped, }\end{array}$

compressed and diameter 1.5 to $2.0 \mathrm{~mm}$. Brown to blackish brown, central portion paler and smooth. Cleft fairly open about 0.7 to $1.00 \mathrm{~mm}$ deep. Testa echinate to muricate, with rough and blunt tubercles of various heights ${ }^{[11]}$ 


\section{Microscopical studies}

The required samples of different organs were cut and removed from the plant and fixed in FAA (Formalin- $5 \mathrm{ml}+$ Acetic acid- $5 \mathrm{ml}+70 \%$ ethyl alcohol-90 ml). After $24 \mathrm{hrs}$ of fixing, the specimens were dehydrated with graded series of tertiary - butyl alcohol as per the schedule given by Sass, 1940. Infiltration of the specimens was carried by gradual addition of paraffin wax (melting point $58-60^{\circ} \mathrm{C}$ ) until TBA solution attained super saturation. The specimens were cast into paraffin blocks ${ }^{[12-15] .}$

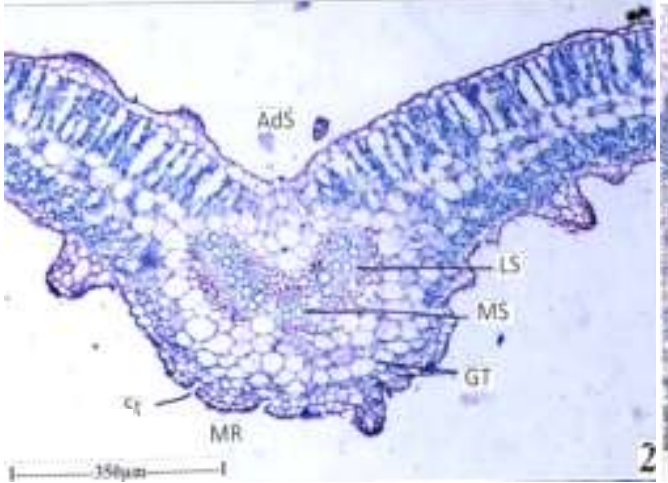

Fig. 2 : Midrib enlarged

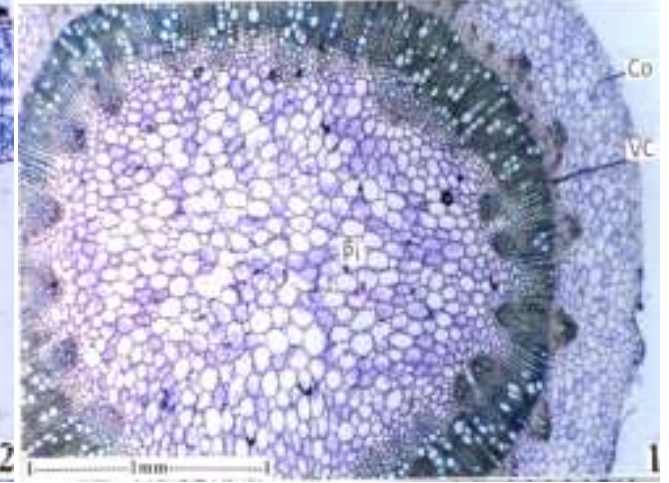

Fig. 3: T.S of the Stem - Ground Plan

Ads : Adaxial strand ; MR :Midrib ;LS : Lateral strand ;

GT : Ground tissue; MS : Median strand; St :Stomata; Pi : Pith; Co: Cortex
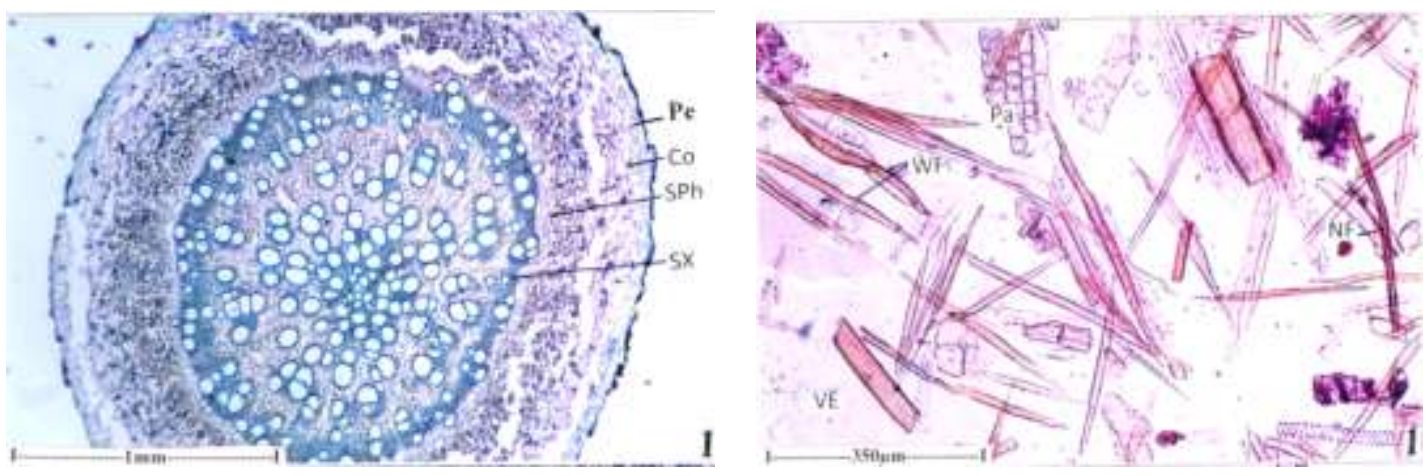

Fig. 4 : T.S of the Root - Entire View

Fig. 5 : Vessel elements and Fibres

Co : Cortex ; Ep :Epidermis ; SPh : Secondary Phloem ; Pa : Parenchyma ;

NF : Narrow fibre ; SX : Secondary xylem ; Pe : Periderm;

VE : Vessel elements ; WF : Wide fibre

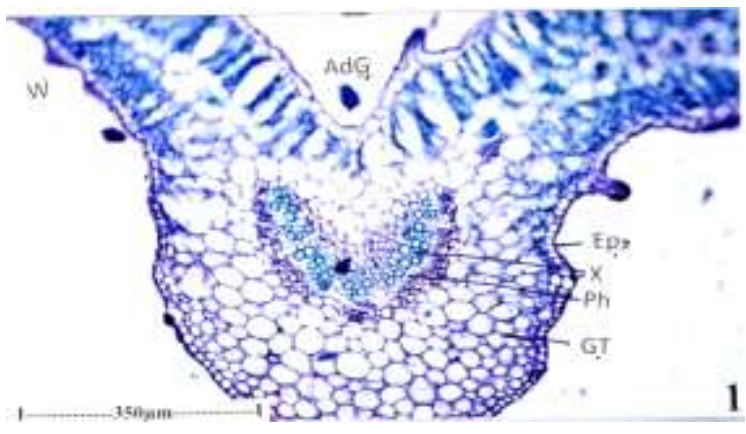

Fig. 6 : T.S of basal (Proximal) part of the petiole abaxial epidermis Showing stomata.

Ec : Epidermal Cell ; AW : Antielinal wall ; GC : Guard Cells 


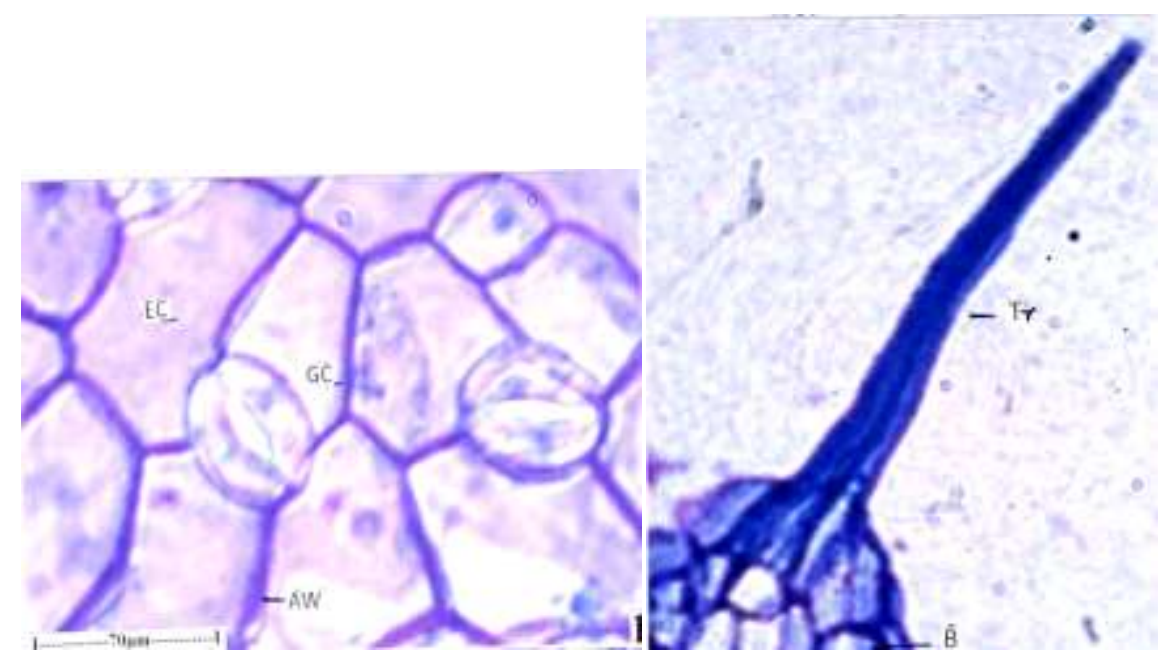

Fig. 8: Paradermal sections of the abaxial epidermis
Fig. 9 : One Trichome enlarged Showing Anomocytic Stomata

\section{Results}

Table 1. Data showing the Quantitative Microscopy for leaves of Cleome chelidonii $^{[16]}$

\begin{tabular}{|l|l|l|}
\hline S.No. & ameters & an \pm SD \\
\hline 1. & n islet number & $\beta \pm 1.3302$ \\
\hline 2. & n termination number & $2 \pm 2.0932$ \\
\hline 3. & Stomatal number (Upper epidermis) & \pm 2.1090 \\
\hline 4. & natal number (Lower epidermis) & \pm 2.1118 \\
\hline 5. & natal index (Upper epidermis) & $8 \pm 0.6881$ \\
\hline 6. & natal index (Lower epidermis) & $\$ 2 \pm 0.6554$ \\
\hline 7. & sade ratio (Upper epidermis) & $\beta \pm 3.1964$ \\
\hline
\end{tabular}

Table 2.Data showing the Physico Chemical Standards of whole plant powder of Cleome chelidonii ${ }^{[17-21]}$

\begin{tabular}{|r|l|l|}
\hline S.No. & Parameters & Mean $(\%) \mathbf{w} / \mathbf{w} \pm$ SD \\
\hline 1. & Total Ash & $10.3 \pm 0.0774$ \\
\hline 2. & Acid in Soluble Ash & $1.7 \pm 0.1897$ \\
\hline 3. & Water soluble Ash & $2.2 \pm 0.1897$ \\
\hline 4. & Sulphated Ash & $4.6 \pm 0.2645$ \\
\hline 5. & Loss on Drying & $1.86 \pm 0.0729$ \\
\hline 6. & Alcohol Soluble Extractive & $1.28 \pm 1.5938$ \\
\hline 7. & Water Soluble Extractive & $0.82 \pm 0.0412$ \\
\hline 8. & Crude Fibre Content & $11.26 \pm 0.4715$ \\
\hline
\end{tabular}


Table 3. Fluorescence Analysis of Extracts and Drug powder of Cleome $_{\text {chelidonii }}{ }^{[2]}$

\begin{tabular}{|l|l|l|l|l|}
\hline \multirow{2}{*}{ Reagents } & Chloroform extract & Drug powder \\
\cline { 2 - 5 } & DL & UVL & DL & UVL \\
\hline Extract as such & Yellow & Yellow & - & - \\
\hline $\begin{array}{l}\text { 1 N Sodium Hydroxide } \\
\text { (aqueous) }\end{array}$ & $\begin{array}{l}\text { Yellowish } \\
\text { brown }\end{array}$ & Dark green & Pale green & Yellowish green \\
\hline $\begin{array}{l}\text { 1 N Sodium Hydroxide } \\
\text { (alcohol) }\end{array}$ & Yellow & Yellow colour & Green & Fluorescent green \\
\hline 1 N Hydrochloric Acid & Brown & Green colour & Brown & Light green \\
\hline 50\% Nitric Acid & Greenish yellow & Yellow colour & Green & Fluorescent green \\
\hline 50\% Sulphuric Acid & Green & Yellowish green & Green & Fluorescent green \\
\hline Methanol & Light green & Green & Green & Fluorescent green \\
\hline Ammonia & Greenish yellow & Dark green & Green & Yellowish green \\
\hline Iodine & Brownish yellow & Yellowish brown & Brown & Light green \\
\hline Ferric Chloride & Greenish brown & Yellow & Green & Light green \\
\hline
\end{tabular}

DL

Day Light

UVL - UV Light

Table 4. Elemental Analysis of Cleome chelidonii ${ }^{[23-25]}$

\begin{tabular}{|l|l|l|}
\hline S. No. & Parameters & Amount \\
\hline 1. & Organic Carbon (\%) & 4.58 \\
\hline 2. & Total Nitrogen $(\%)$ & 1.79 \\
\hline 3. & Total Phosphorus (\%) & 0.87 \\
\hline 4. & Total Potassium $(\%)$ & 4.28 \\
\hline 5. & Total Sodium $(\%)$ & 0.69 \\
\hline 6. & Total Calcium (\%) & 5.23 \\
\hline 7. & Total Magnesium (\%) & 3.91 \\
\hline 8. & Total Sulphur $(\%)$ & 0.52 \\
\hline 9. & Total Zinc $(\mathrm{ppm})$ & 4.53 \\
\hline 10. & Total Copper $(\mathrm{ppm})$ & 1.29 \\
\hline 11. & Total Iron $(\mathrm{ppm})$ & 56.32 \\
\hline 12. & Total Manganese (ppm) & 12.54 \\
\hline 13. & Total Boron (ppm) & 0.12 \\
\hline 14. & Total Molybdenum (ppm) & 0.16 \\
\hline 15. & Heavy Metals (ppm) & Nil \\
\hline
\end{tabular}

Table 5. Quantitative estimation of drug powder of Cleome chelidonii

\begin{tabular}{|l|l|l|}
\hline S.No. & Parameters & Total amount in $\mathbf{~ m g} / \mathbf{k g}$ \\
\hline 1. & Total alkaloids & 0.79 \\
\hline 2. & Total Flavanoids & 2.54 \\
\hline 3. & Tannin & 0.79 \\
\hline 4. & Lignin & 0.87 \\
\hline 5. & Glycosides & 0.06 \\
\hline
\end{tabular}




\section{Phytochemical Studies}

Table 6.Data showing the preliminary phytochemical screening of Cleome chelidonii $^{[16]}$

\begin{tabular}{|c|c|c|c|c|c|c|}
\hline Phytoconstituents & $\begin{array}{l}\text { Petroleum } \\
\text { ether } \\
\text { extract }\end{array}$ & $\begin{array}{l}\text { n-hexane } \\
\text { extract }\end{array}$ & $\begin{array}{l}\text { Chloroform } \\
\text { extract }\end{array}$ & $\begin{array}{l}\text { Acetone } \\
\text { extract }\end{array}$ & $\begin{array}{l}\text { Methanol } \\
\text { extract }\end{array}$ & $\begin{array}{l}\text { Aqueous } \\
\text { extract }\end{array}$ \\
\hline Alkaloids & $(-)$ & $(-)$ & $(+)$ & $(+)$ & $(+)$ & $(-)$ \\
\hline Carbohydrates & $(-)$ & $(-)$ & $(+)$ & $(+)$ & $(+)$ & $(-)$ \\
\hline Glycosides & $(-)$ & $(-)$ & $(+)$ & $(+)$ & $(+)$ & $(-)$ \\
\hline Flavonoids & $(-)$ & $(-)$ & $(+)$ & $(+)$ & $(+)$ & $(-)$ \\
\hline Phytosterols & $(+)$ & $(+)$ & $(+)$ & $(+)$ & $(+)$ & $(+)$ \\
\hline Fixed oils and Fats & $(-)$ & $(-)$ & $(+)$ & $(-)$ & $(-)$ & $(-)$ \\
\hline Saponins & $(-)$ & $(-)$ & $(-)$ & $(-)$ & $(-)$ & $(-)$ \\
\hline Phenolic & $(-)$ & $(-)$ & $(+)$ & $(+)$ & $(+)$ & $(+)$ \\
\hline Lignins & $(+)$ & $(+)$ & $(+)$ & $(+)$ & $(+)$ & $(+)$ \\
\hline Proteins and free & $(+)$ & $(+)$ & $(+)$ & $(+)$ & $(+)$ & $(+)$ \\
\hline Gums & $(-)$ & $(-)$ & $(-)$ & $(+)$ & $(-)$ & $(+)$ \\
\hline
\end{tabular}

(+) Positive

( - ) Negative

Table 7.Thin Layer Chromatography of Chloroform extract of Cleome chelidonii $^{[26-29]}$

\begin{tabular}{|c|c|c|c|c|c|}
\hline S.No. & Phytoconstituents & Mobile phase & Detecting agent & $\begin{array}{l}\text { No. of } \\
\text { spot }\end{array}$ & $\mathbf{R}_{\mathrm{f}}$ value \\
\hline 1. & Alkaloids & $\begin{array}{l}\text { Benzene: Ethanol } \\
\left(9^{\prime}: 1\right)\end{array}$ & $\begin{array}{l}\text { Dragendorff's } \\
\text { reagent }\end{array}$ & 1 & 0.34 \\
\hline 2. & Glycosides & $\begin{array}{l}\text { Toluene: } \\
\text { Ethylacetate }(7: 3)\end{array}$ & $\begin{array}{l}\text { Anisaldehydesulp } \\
\text { huric acid }\end{array}$ & 2 & \begin{tabular}{|l|}
0.37 \\
0.74 \\
\end{tabular} \\
\hline 3. & Flavonoids & $\begin{array}{l}\text { Petroleum ether : } \\
\text { Ethylacetate }(2: 1)\end{array}$ & Iodine vapour & 4 & $\begin{array}{l}0.56 \\
0.85 \\
0.89 \\
0.95\end{array}$ \\
\hline 4. & Steroids & $\begin{array}{l}\text { Benzene: } \\
\text { Ethyl acetate (9:1) }\end{array}$ & $\begin{array}{l}\text { Vanillin in } \\
\text { sulphuric acid }\end{array}$ & 3 & \begin{tabular}{|l|}
0.1 \\
0.75 \\
0.78 \\
\end{tabular} \\
\hline 5. & Essential oil & Chloroform & $\begin{array}{l}\text { Vanillin } \\
\text { sulphuric acid }\end{array}$ & 2 & $\begin{array}{l}0.48 \\
0.73 \\
\end{array}$ \\
\hline
\end{tabular}

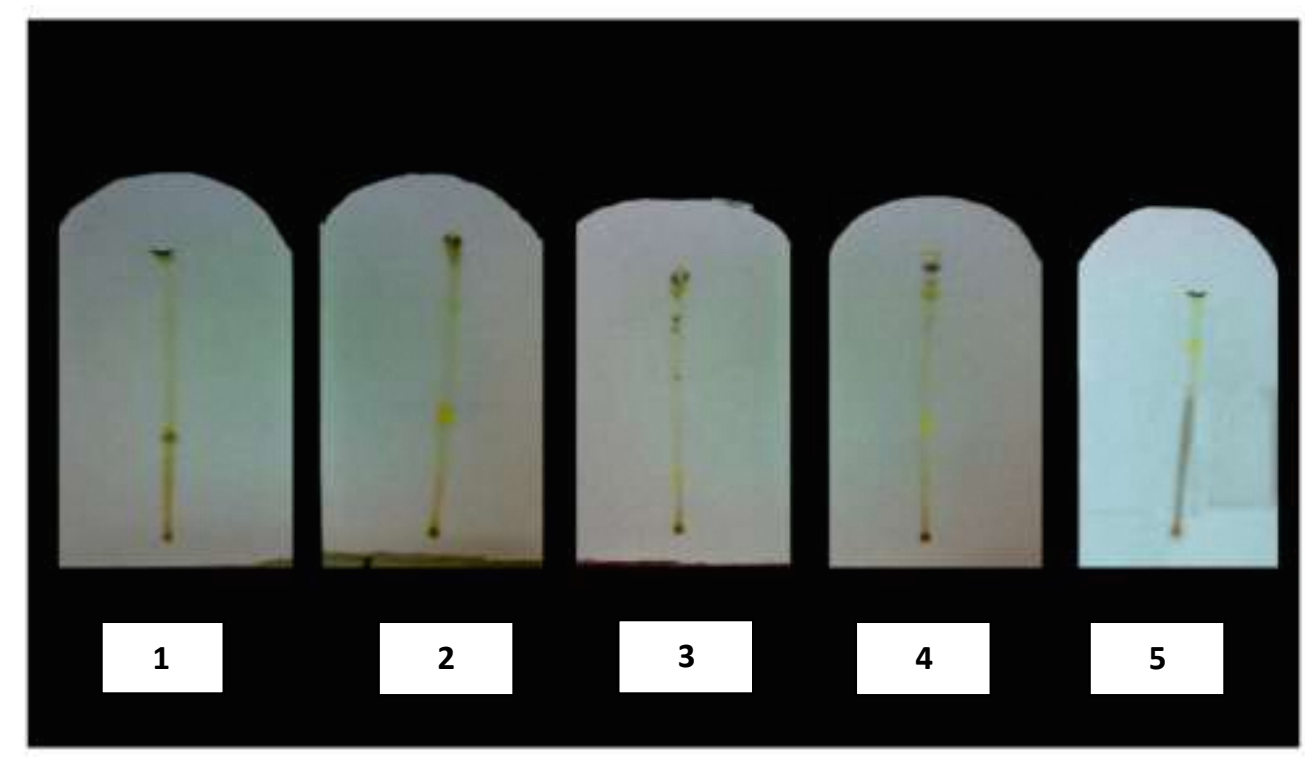

Fig.10: Thin 


\section{Layer Chromatography of Chloroform extract of Cleome chelidonii}

1.Alkaloids ; 2. Glycosides ; 3.Flavonoids ; 4.Steroids ; 5. Essential oil

\section{Column chromatography}

The chloroform, acetone and methanol extracts of Cleome chelidonii were subjected to column chromatography ${ }^{[30-33]}$

An yellow crystalline compound was obtained by Column Chromatography in the fractions of Chloroform extract (Chloroform 100) and was named CCC1(Cleome chelidonii compound no.1)

\section{High Performance Thin Layer Chromatography ${ }^{[22]}$}

The chloroform extract of Cleome chelidonii was subjected to HPTLC studies

\section{Chromatographic condition for HPTLC Finger print}

The chloroform extract of whole plant of Cleome chelidonii was run for HPTLC studies.

The Mobile phase used was n-Hexane: Ethyl acetate: Formic Acid: Acetic acid (70:25:2.5:2.5).

$25 \mathrm{mg} / \mathrm{ml}$ concentration of the sample was taken and the applied volume was $2.5,5,10 \& 15 \mu \mathrm{l}$.

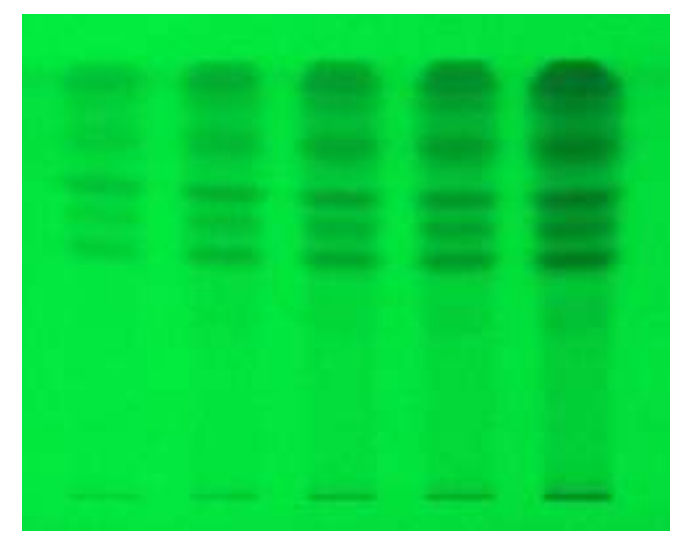

Fig.11 : HPTLC of Chloroform extract Under UV Light (254 nm)

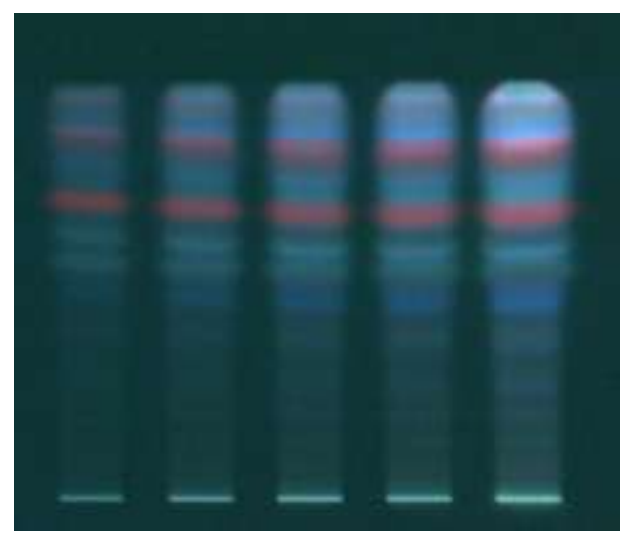

Fig.12 : HPTLC of Chloroform extract Under UV Light (366 nm)
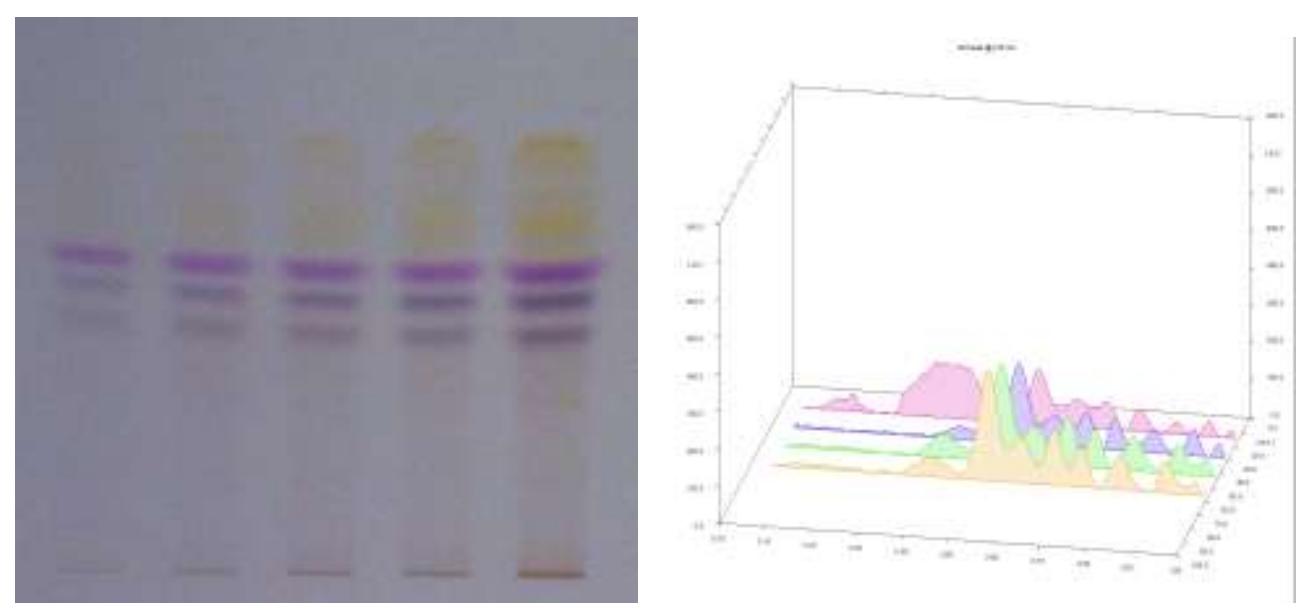

Fig. 13: HPTLC of Chloroform extract Fig. 14 : HPTLC of Chloroform extract Under Visible Ligh (All Tracks at Wavelength)

\section{Discussion}


The evaluation of Pharmacognostical parameters may ensure the identity and authenticity of Plant Cleome chelidonii. The leaf, petiole, stem, root of Cleome chelidonii were subjected to microscopical studies.

The Plant Cleome chelidonii Linn. is an erect herb, much branched, the leaves are 1- or 3-foliate at the top and 5- or 7-foliate at the base. The leaf exhibits dorsiventral symmetry with prominent midrib and fairly thick lamina.The lamina consists of fairly thick epidermal layer of spindle shaped larger cells with anomocytic stomata. In the mesophyll tissue, two horizontal rows of dilated circular hyaline cells are observed. The covering trichomes are present in the leaf. Seeds are asymmetrical, spherical to oval, comma shaped. The quantitative microscopical results were reported in Table 1.

Powder analysis of the whole plant of Cleome chelidonii showed the presence of wide and narrow fibres, vessel elements with perforation plate and squarish shaped parenchyma cells.

The physico chemical standard values such as total ash, water soluble ash, acid insoluble ash, sulphated ash, loss on drying, water soluble extractive value, alcohol soluble extractive value and crude fibre content were reported in Table 2. The alcohol soluble extractive values were higher than water soluble extractive values.

The fluorescence analysis of extracts and powders with different reagents were studied in day light and UV light and reported in Table 3. The results of elemental analysis and quantitative estimation of drug powder were reported in Table $4 \& 5$.

All the extracts were subjected to preliminary phytochemical investigation. More number of phytoconstituents like alkaloids, glycosides, flavanoids, phytosterols, essential oil, proteins and aminoacids were found to be present in chloroform, acetone and methanolic extracts and the results were reported in Table 6. All the extracts were subjected to Thin Layer Chromatography (TLC) and the number of spots with its $R_{f}$ values were determined and reported in Table 7.

From the results of the Thin Layer Chromatography (TLC), it was observed that more prominent spots were obtained for the Chloroform extract of Cleome chelidonii and was subjected to Column chromatography. The Chloroform extract of Cleome chelidoniigave an Yellow crystalline Compound (CCC1) in the fraction of Chloroform (100\%) in the Column chromatography.

The isolated compound CCC1 was crystalline in nature, yellow in colour, odourless and bitter in taste with melting point $\left(175^{\circ}-177^{\circ} \mathrm{C}\right)$, soluble in organic solvents. The isolated compound CCC1 gave a $\mathrm{R}_{\mathrm{f}}$ value of 0.56 when subjected to Thin Layer Chromatography which coincided with one of the $R_{f}$ value obtained in the TLC of chloroform extract for flavanoids. The HPTLC Studies for the Chloroform extract were reported. The $\mathrm{R}_{\mathrm{f}}$ value 0.56 of the TLC complied with the HPTLC studies. In future, spectral studies, Gas chromatography have been planned to identify the isolated unknown compound CCC1.

\section{Conclusion}

In the present study, the plant Cleome chelidonii was selected to explore the scientific information on Pharmacognostical and Phytochemical aspects. The parameters which are reported under Pharmacognostical and Phytochemical studies could be used for botanical identification of the drug in the crude form and preparation of Monograph of the plant Cleome chelidonii.

\section{Acknowledgement}

The authors wish to thank the Management of Periyar College of Pharmaceutical Sciences, Tiruchirappalli, Tamil Nadu, India for having rendered their support in carrying out this research at the Institution.

\section{References}

1. Kamraj VP, Herbal Medicine. Current Sciences, 2000, 78 (1): 35 -39. 
2. Recent Advances in Indian Herbal Drug Research Guest Editor: Thomas Paul Asir Devasagayam Current Status of Herbal Drugs in India: An Overview Ashok DBVaidya and Thomas PADevasagayam, Journal of Clinical Biochemistry and Nutrition, 2007, 41: 1-11.

3. Nadkarni A.K.,Indian Materia Medica, Popular Prakashan, Bombay, 1976, Vol-2,350.

4. Mathew K.M., Further illustration on the flora of the Tamilnadu Carnatic, The Rabinet Herbarium, St. Joseph's College, Tiruchirappalli, 11.

5. Chopra R.N., Nayar S.L., Chopra L.C., Glossary of Indian medicinal plants, National Institute of Science Communication, New Delhi, 1996, 70.

6. Vijayakumar P, BirBhagadur. Seed Morphology of Thirteen Species of Cleome L. Journal of Indian Botanical Society, 1978, 57: 39-46.

7. Songsak T, Lockwood GB. Isolation of glucosinolates of seven medicinal plants from Thailand including Cleome chelidonii.Fitoterapia, 2002, 73(3): 209-216.

8. Parimalakrishana S, DeyA, Smith A, Manavala R. Evaluation of the anti-inflammatory, antinoniceptive and antipyretic effects of methanol extract of Cleome chelidonii.Indian Journal of Biological Chemical Sciences, 2007, 1(3): $284-287$.

9. Parimalakrishnan S, AkalankaDey, Manavalan R. Effect of the methanolic extract of Cleome chelidonii on drug metabolizing enzymes antioxidant status and chemomodulatory efficacy in mice. Journal of Basic and Applied Sciences, 2009, 5(1): 37 - 46.

10. Aparadh VT, Karadge BA. Seed ornamentation studies in some Cleome species including Cleome chelidonii. Bioinfolet,2010, 7(1): 73-76.

11. Kirtikar K.R., Basu B.D.,Indian Medicinal Plants, Bishan Singh Mahendra Pal Singh, Dehra Dun, 1993, $186 \& 187$.

12. O' Biren TP,Feder N,Mc Cull ME.Polychromatic Staining of Plant Cell walls by toluidine blue-O, Protoplasme, 1964, 59; 364-373.

13. Johansen D.A.,Plant Microtechnique, McGraw Hill Book Co, New York, 1940, 523.

14. Metcalfe C.R.,Chalk L.,Anatomy of the Dicotyledons, Oxford: Clarendon Press, Vol. I, 1950, 276.

15. Easu K.,Anatomy of Seed Plants, John Wiley and sons, New York, 1964, 767.

16. Kokate C.K., Practical Pharmacognosy,VallabhPrakashan,IV edition, Delhi, 1994, 127-128, 108 - 109 \& 286.

17. India Pharmacopoeia, $2^{\text {nd }}$ edition, Manager of Publication, Delhi, 1966, 947-950.

18. Wallis T.E., Text Book of Pharmacognosy, Fifth Edition,CBS Publishers and Distributors, Delhi, 1985, 562.

19. Patel N.M., Jain V.C., Shah D.P., Pharmacognosy, S.Vikas Publisher, 2007, 13-14.

20. Gupta M.K., Sharma P.K.,Textbook of Pharmacognosy,Vol -III, First Edition, PragathiPublishers, 2009, 116-117.

21. Khandelwal K.R.,Practical Pharmacognosy, Techniques and Experiments, Nirali Prakashan, India, 2004, $146-148$ \& 158.

22. Saharan V.A., Moond M.K., Chouhan P.C. and Gupta M.K., Principles of Pharmacognosy,Agrobios Publisher, India, 2001, 134, 124 - 126 \&138-139.

23. Chaudhary B.L.,Pharmaceutical Biology, Apex publishing house, 2007,225- 226.

24. William Kemp., Organic Spectroscopy, $2^{\text {nd }}$ edition. Macmillan publisher, India, 1987, 144 - 151.

25. Kaur H.,Spectroscopy,PragatiPrakashan Publishers, Uttar Pradesh, $2008161-198$.

26. Egonstahl, Thin Layer Chromatography, $2^{\text {nd }}$ edition,Springer, Delhi, 2005, 105.

27. BirenN. Shah, Jalalpure S..S, and Nayak B.S., Seth A.K., Textbook of Pharmacognosy and Phytochemistry, Elsevier Health Sciences, 2009, 256.

28. Harborne J.B., Phytochemical Methods, A guide to Modern Technique of plant Analysis, $3^{\text {rd }}$ edition, Springer Publication, 2007, 17-25, 52-80 \&292- 293.

29. Kamalesh Bansal, Chromatography, Campus books international, 2000, 75-76.

30. Mabry T.J., Markham K.R., Thomas M.B.,The systematic identification of Flavonoid, Academic Press, London, 1970, $16-20$.

31. Markham K.R.,Technique of flavonoid identification, Academic Press, London, 1982, 20.

32. Clarke, Isolation and Identification of drugs, II edition, The plant Pharmaceutical Press, London, 1986, 90-95.

33. Raymond P.W. Scott., Techniques and Practice of Chromatography, Marcel Dekker Edition, New York, 2002, 324. 